\title{
O ENIGMA DA DEMOCRACIA EM MARX
}

\section{Thamy Pogrebinschi}

Marx afirma, na Crítica da filosofia do direito de Hegel, que "a democracia é o enigma resolvido de toda constituição" (Marx, 1992a [1843], p. 87). Mais do que conceber a democracia como um enigma, Marx a concebe como um "enigma resolvido" (aufgelöste Rätsel). Um enigma resolvido é aquele que se sabe ser a solução do próprio problema para o qual aponta. Trata-se de um conceito que contém em si simultaneamente um enigma e a solução capaz de decifrá-lo. Na qualidade de enigma resolvido de toda constituição, a democracia marxiana apresenta-se como resposta para os problemas levantados pelas formas políticas. O principal destes problemas, de acordo com Marx, diz respeito à contradição entre o Estado e a sociedade civil. É este, afinal, o enigma da modernidade política, que o mais astuto dos discípulos de Hegel soube logo cedo diagnosticar. Ao romper

Artigo recebido em agosto/2005

Aprovado em agosto/2006 com seu mestre e recusar à política qualquer forma de mediação, Marx faz de seu conceito de verdadeira democracia (wahre Demokratie) a resolução do enigma colocado pelo Estado moderno.

Isso explica por que "na democracia o Estado abstrato deixa de ser o momento governante" (Idem, p. 89). Quando a democracia atinge a sua verdade, ela supera a si mesma, encontrando sua real expressão no processo de desvanecimento do Estado e da sociedade civil única solução possível para dois extremos reais que, como tais, não admitem mediação. Com a superação (Aufhebung) destes, o político encontra-se definitivamente com o social, e nenhuma relação de subordinação ou dependência passa a ser possível entre uma e outra esfera. No entanto, a realização da democracia foi modernamente concebida na forma de um "Estado democrático": uma aliança impertinente entre dois termos inconciliáveis, afinal "todas as formas de Estado têm a democracia como sua verdade e por esta 
razão elas são falsas, na medida em que não são a democracia" (Idem, ibidem).

O Estado que desvanece com a verdadeira democracia consiste na forma ilusória daquela que deve ser a comunidade política real (wirklich Gemeinschaft), ou seja, ele é um produto da alienação política. As "falsas democracias", ou as democracias que não são verdadeiras, necessariamente coincidem com uma forma de Estado, seja ela aristocrática, monárquica ou republicana. A verdadeira democracia, por sua vez, não se identifica com nenhuma dessas formas e, ao contrário, se insurge em oposição a elas. A concepção de democracia de Marx é concomitantemente uma democracia para além do Estado (Avineri, 1968, p. 38) e contra o Estado (Abensour, 1998 [1997]) e, nesse sentido, ela rejeita todas as formas políticas que acompanham a moderna idéia de Estado. Por isso, o principal pressuposto do pensamento político de Marx é justamente o de que a contradição entre o Estado e a sociedade civil deve ser superada para que, então, se possa encontrar o verdadeiro significado da democracia. E isso implica pensar a política para além do Estado; ou melhor, isso implica conceber uma outra forma de organização política que possa servir de lugar à democracia.

O objetivo deste artigo consiste em examinar o conceito marxiano de verdadeira democracia, tal como desenvolvido, sobretudo, na Crítica da filosofia do direito de Hegel, de maneira a indicar o modo pelo qual ele se apresenta como o "enigma resolvido" das formas modernas de organização política. Nesse sentido, argumentarei que tal enigma aponta para a contradição entre Estado e sociedade civil que, para Marx, constitui a principal característica da modernidade política. Em conseqüência, argumentarei também que como solução do enigma que revela, a "verdadeira democracia" implica na superação daquela contradição, a qual apenas pode se dar mediante a criação de um novo lugar para a política: a comunidade real fundada em uma livre associação de homens igualmente livres.

\section{A democracia como a verdade da comunidade}

Como conceber a verdadeira democracia? Como ela resolve o enigma que Marx identifica na política moderna, isto é, a contradição entre o Estado e a sociedade civil? Em primeiro lugar, é preciso entender a verdadeira democracia como um conceito que é em sua essência normativo. É o que indica Engels em um texto de 1845, intitulado "O festival das nações em Londres":

Não estamos falando sobre a democracia real que a Europa inteira apressa-se em adotar e que consiste em uma democracia bastante especial, diferente de todas as democracias anteriores. Estamos falando sobre uma democracia bastante diferente que representa o meio-termo entre as democracias grega, romana, americana e francesa; em resumo, estamos falando sobre o conceito de democracia. Não estamos falando sobre as coisas que pertencem ao século XIX, e que são ruins e efêmeras, mas sobre categorias que são eternas e que existiam antes de "as montanhas terem sido criadas”. Em suma, não estamos discutindo aquilo sobre o que se tem falado, mas uma coisa bastante diferente (Engels, 1845, p. 3).

A excepcionalidade do conceito marxiano de democracia encontra-se revelada nestas palavras de Engels. Não se trata da "democracia real", aquela que se verifica hoje empiricamente ao redor do mundo, e que no século XIX a "Europa inteira" estava "apressando-se em adotar". Trata-se de uma democracia "bastante diferente", inclusive diferente "de todas as democracias anteriores" e desta "sobre a qual se tem falado", na época de Marx e na nossa. Não se encontra, esta democracia, entre as "coisas que pertencem ao século XIX". Ao contrário, trata-se de algo que esteve desde sempre posto, na forma de "categorias que são eternas" e que nasce quando surgem os homens; trata-se de um "meio-termo" entre as democracias grega, romana, americana e francesa. ${ }^{1}$ Trata-se, afinal, da essência, do ser (Wesen), da democracia; aquilo que permite que ela possa ser formulada na forma de um conceito e, como tal, concebida como o "vir a ser" (Werden) do político, uma concepção normativa sobre como a política pode ser uma vez concebida para além do Estado moderno com o qual ela historicamente se identifica.

Duas oposições destacam-se aqui: o conceito de democracia que se opõe à democracia real, e as categorias que são eternas e se contrapõem às coisas pertencentes ao século XIX. O que entender 
disso? Primeiro, não se trata de descrever, empiricamente, uma realidade, mas de se opor a ela por meio de um conceito capaz de subvertê-la, capaz de conduzi-la à sua própria transformação. Segundo, trata-se de entender este conceito propriamente como uma categoria epistemológica e como um princípio de ação que não se verifica em uma realidade estática, nem em um momento concreto e determinado; ao contrário, trata-se de entender a democracia como um "conceito de movimento" que se espraia pelo espaço e pelo tempo, da Grécia à América, de Roma à França. Terceiro, esse movimento não pode ser aprisionado em um momento: se a democracia opõe-se às "coisas do século XIX", o conceito de verdadeira democracia não se identifica com a modernidade política; ele busca superá-la.

Foi com o intuito de compreender o enigma da modernidade política, a separação entre o Estado e a sociedade civil, que, desenganado com o fechamento de sua Gazeta Renana pelo governo prussiano, Marx refugia-se em Kreuznach, onde, entre março e agosto de 1843, irá formular a crítica que marcou seu rompimento definitivo com Hegel. Nesse profícuo período de sua atividade intelectual, Marx, buscando prover soluções para os problemas deixados em aberto por Hegel, elabora o conceito de verdadeira democracia e prepara sua primeira abordagem do comunismo, o que resultará na nomeação, no ano seguinte, daquele que viria a ser o seu sujeito histórico, o proletariado.

Em Hegel, a contradição entre o Estado e a sociedade civil remete diretamente à dicotomia entre o particular e o universal. A "esfera política", ou o Estado, apresenta-se como a esfera do universal, ao passo que a "esfera socioeconômica", ou a sociedade civil, é a esfera do particular. Nessas duas dimensões separadas, a particularidade dos interesses privados ou pessoais contrapõe-se à universalidade dos interesses "públicos" ou estatais. Conseqüentemente, a relação dicotômica entre o universal e o particular, por sua vez, converte-se na relação também dicotômica entre o político e o social. Como então superar esses dualismos? Como fundir o universal e o particular em uma unidade que resolva o seu antagonismo, conciliando-os e tornando-os uma substância única?
A intuição mais aguçada de Hegel foi sua percepção da separação da sociedade civil e política como uma contradição. Mas seu erro foi ter-se contentado com a aparência de sua dissolução, e deixar passar o que importa; enquanto as "assim chamadas teorias" que ele menospreza demandam a separação das classes civil e política, e corretamente, pois elas expressam uma conseqüência da sociedade moderna (Marx, 1992a [1843], p. 141).

Hegel reconhece o problema, nomeia-o, mas não se mostra capaz de resolvê-lo. Ilude-se ao crer serem os estamentos uma espécie de síntese entre o Estado e a sociedade civil, uma vez que eles teriam a função de mediar a relação entre um e outra. Para Marx, isso consiste em uma construção logicamente absurda, que apenas pode ter lugar no misticismo da dialética idealista. Contra Hegel, Marx concebe os estamentos como a mais pura expressão da contradição entre Estado e sociedade civil: "os estamentos políticos não são nada senão a expressão fática da verdadeira relação entre o Estado e a sociedade civil - sua separação" (Idem, p. 141). Portanto, crer que os estamentos operam como síntese da contradição entre Estado e sociedade civil, e mais, crer que uma contradição possa ser resolvida por meio de uma mediação, implica crer em uma solução ilusória e logicamente falsa.

Extremos reais [wirkliche Extreme] não podem ser mediados precisamente porque são extremos reais. Nem precisam eles de mediação, porque são totalmente opostos. Eles não têm nada em comum um com o outro, não têm necessidade um do outro, não se complementam um ao outro (Idem, p. 155).

Extremos reais não são mediáveis. Em suas essências opostas, os extremos reais não podem existir um pelo outro, não podem se completar. A oposição real de essências, uma contradição (Widerspruch) verdadeira, apenas pode ser resolvida quando seus termos se excluem mutuamente. A única relação possível entre os dois termos de uma contradição, portanto, é a de exclusão. Para que cesse a oposição entre eles, os dois extremos precisam ser definitiva e simultaneamente eliminados.

A fim de resolver este que seria o "dualismo fundamental da lógica de Hegel”, ou seja, a oposi- 
ção entre universalidade e particularidade como expressão da contradição entre Estado e sociedade civil, Marx sabe, portanto, que as mediações não bastam. O problema da lógica hegeliana consistia, segundo Marx, em não perceber que entre dois extremos não há mediação possível, de modo que não há mediação possível entre o Estado e a sociedade civil. É por isso que Marx mostra que a representação, por exemplo, não serve à democracia, pois ela constitui uma mediação e, como tal, não serve para resolver aquela contradição. Ao contrário, a representação, seja ela estamental como no feudalismo, seja ela "política" como na modernidade, apenas aprofunda a contradição entre o Estado e a sociedade civil. A representação não é nada além de uma forma de mediação, ou seja, implica em uma solução falsa e ilusória para a principal contradição engendrada com e pela modernidade política. Uma contradição real, o antagonismo entre dois extremos reais, portanto, apenas pode ser resolvida por meio da negação da negação, isto é, do Aufhebung destes dois termos, simultaneamente. O desvanecimento do Estado e da sociedade civil consiste, assim, na única maneira de resolver a contradição que entre eles se expressa. Foi este o enigma que Hegel não soube decifrar.

Já em 1843, por conseguinte, Marx forma uma convicção da qual jamais se desfará, qual seja, a idéia de que a democracia não pode se realizar senão em uma sociedade onde os homens não mais se alienam por meio de mediações, sejam elas políticas, sejam econômicas. Isso implica reconhecer que a democracia não pode se realizar verdadeiramente no Estado moderno, tampouco na sociedade civil que a ele se contrapõe. No primeiro livro de O capital, quando seu afastamento de Hegel não mais se questiona, Marx volta a argumentar que as contradições não devem ser resolvidas por meio de uma superação abstrata, como são as mediações, mas sim pela dissolução dos termos opostos mediante a criação de uma forma nova, na qual as contradições a um só tempo resolvem-se e reconciliam-se.

Vimos em um capítulo anterior que a troca de mercadorias implica condições contraditórias e mutuamente exclusivas. A diferenciação das mercadorias em mercadoria e dinheiro não abole essas contradições, mas, antes, provê a forma dentro da qual elas têm espaço para se movimentar. Este é, em geral, o modo pelo qual contradições reais são resolvidas. Por exemplo, é uma contradição descrever um corpo como constantemente caindo sobre outro, e como, ao mesmo tempo, constantemente voando para longe dele. A elipse é uma forma de movimento dentro da qual esta contradição é ao mesmo tempo realizada e resolvida (Marx, 1992 [1867], p. 198).

No que toca à contradição entre o Estado e a sociedade civil, o enigma resolve-se na forma elíptica da comunidade. É a comunidade a "forma de movimento", ou uma forma em movimento, que resolve a contradição ao mesmo tempo em que a realiza. Conforme argumentei alhures, a comunidade é o conceito marxiano que significa, simultaneamente, Estado e sociedade civil, precisamente por não ser, ao mesmo tempo, nenhum dos dois. A unidade constituída pela comunidade tem como fundamento os sujeitos políticos reais, os homens que realizam a sua liberdade na e através da associação. Na comunidade real não se encontra mais em jogo o problema da procedência ou derivação da esfera socioeconômica e da esfera política. A realidade contida na idéia de comunidade torna desnecessário argumentar, contra Hegel, que o Estado deriva da sociedade civil e não o contrário. ${ }^{2}$

A comunidade como a forma política da sociedade comunista que viria se realizar após o desvanecimento do Estado e da sociedade civil não coincide com um suposto apelo marxiano de retorno às formas comunitárias primitivas - como a Gemeinwesen do medievo germânico ou os artéis russos -, onde os modos de produção précapitalista asseguravam a unidade do social e do político por meio da unidade entre o homem e o produto de seu trabalho na propriedade comunitária. Tampouco, ao idealizar a sociedade pósrevolucionária, Marx tinha em mente um retorno às formas políticas antigas, nas quais a união entre o particular da sociedade civil e o universal do Estado supostamente se encontraram. Nem mesmo as comunidades feudais da Idade Média ou a pólis grega, que constituem exemplos recorrentes na obra de Marx da unidade entre o Estado e a sociedade civil, viriam a ser convocadas a fim de restabelecer a unidade desejada entre o universal e o particular. Essas duas formas políticas, 
afinal, traziam consigo o inconveniente da ausência de liberdade, quando não da própria servidão.

Na Idade Média, a vida do povo era idêntica à vida do Estado (i.e, vida política). O homem era o princípio real do Estado, mas o homem não era livre. Conseqüentemente havia uma democracia da não-liberdade, um sistema perfeito de alienação. A antítese abstrata refletida disto pode ser encontrada apenas no mundo moderno. A Idade Média foi uma idade do dualismo real; o mundo moderno é a idade do dualismo abstrato (Marx, 1992a [1843], p. 90).

A recusa da modernidade não pode, portanto, ser compreendida como um elogio à pré-modernidade. Marx escrevia contra o seu tempo, mas em favor do nosso tempo. Seu pensamento revela-se, ainda, como uma alternativa para uma modernidade política que muito pouco se alterou desde o século XIX. O meio que Marx encontra para clamar pela possibilidade de reunificação entre o universal e o particular é a verdadeira democracia. Um conceito que não se apresenta como abstração justamente por consistir, ele mesmo, em uma antiabstração; um conceito desenvolvido não como uma abstração da realidade existente, mas como uma projeção normativa do que ela pode vir a ser, na forma de um princípio de concretização: "apenas a democracia é a verdadeira unidade do particular e do universal" (Idem, p. 88).

A verdadeira democracia, por conseguinte, consiste no momento da união entre o universal e o particular; no momento da fusão entre as esferas política e social; no momento do reencontro entre o indivíduo egoísta da sociedade civil e o cidadão abstrato do Estado. O lugar onde o dualismo abstrato da modernidade se resolve e os extremos reais se reunificam é a comunidade. Ao clamar pelo Aufhebung do Estado e da sociedade civil, isto é, seu desvanecimento, Marx busca também transcender todos os demais dualismos que derivam da separação que existia entre eles. Assim, a comunidade, como forma em movimento, como um uno múltiplo fundado na associação, traz para dentro de si o universal e o particular, o social e o político, o homem e o cidadão. Os dualismos característicos do pensamento político moderno encontram abrigo na unidade da comunidade.

Assim entende-se por que, "na democracia, o princípio formal é idêntico ao princípio material"
(Idem, p. 88), o que equivale a dizer que "a democracia é ao mesmo tempo forma e conteúdo" (Idem, p. 87). Há uma indissociabilidade entre a comunidade e a democracia: a comunidade é a forma política da democracia, ao passo que esta consiste no único conteúdo que pode preencher aquela. Por conseguinte, na verdadeira democracia não há sentido conceber o "social" e o "político" como duas dimensões separadas. Assim como o universal se identifica com o particular, e o formal, com o material, também o político é ele mesmo o social. Nenhum desses conceitos adquire conteúdo enquanto formas separadas: sua substância é conferida por sua unidade. O princípio material reatualiza-se constante e incessantemente, reconstruindo a sua própria forma; o particular constitui-se na sua própria universalização; o político, por sua vez, só constitui-se como político na medida em que é social, e vice-versa.

Na democracia, o Estado como particular é apenas particular, e como universal ele é realmente universal; ou seja, não é algo determinado, destacado de outros conteúdos. Nos tempos modernos, os Franceses entenderam isso como significando que o Estado político desaparece em uma verdadeira democracia. Isso está correto no sentido de que o Estado político, a constituição, não é mais equivalente ao todo (Idem, p. 88).

O que está em jogo aqui? O reconhecimento da incompletude do Estado moderno que, separado da sociedade civil, formaliza o divórcio entre outros conteúdos que supostamente deveriam estar associados, como, no caso, o particular e o universal. Em qualquer regime político - mesmo em uma democracia que não seja a "verdadeira democracia" -, o Estado necessariamente apresenta-se de forma incompleta, pois se revela incapaz de constituir-se como o "todo", que seria justamente o encontro entre o social e o político, o homem e o cidadão, o universal e o particular, e todos os demais dualismos criados com a modernidade política e formalizados com a separação entre a sociedade e o Estado. Para superar esses dualismos é preciso superar o Estado; esta é a primeira lição de um conceito de democracia que almeja ter a sua verdade revelada. ${ }^{3}$

Percebe-se como o enigma simultaneamente formula-se e soluciona-se: com os tempos moder- 
nos, o Estado separa-se da sociedade; o Estado moderno é o símbolo desta separação, e a sua relação com a sociedade passa a ter a forma de um antagonismo. Para que essa contradição seja desfeita é preciso desfazer o Estado. Com o seu desaparecimento, desaparecerá também a sociedade que, afinal, dele depende para assumir uma existência política. Apenas o desvanecimento dessas duas esferas propiciará o surgimento de uma nova forma de organização política, na qual tal separação não tenha sentido uma vez que nela se realizaria a união completa - um "todo" - entre todos os elementos outrora separados e que apenas podem ser apreendidos conjuntamente. Para que esse "todo" seja alcançado e constituído, o Estado, que representa sua impossibilidade permanente, deve necessariamente ser superado.

O Estado desaparece em uma verdadeira democracia exatamente porque nela as antinomias e os dualismos modernos deixam de ter sentido; a verdadeira democracia, por sua vez, só pode realizar-se em uma forma de organização do político que se substitua ao Estado moderno. Assim, quando Marx afirma que o Estado desaparece, ele tem em vista um movimento de mão dupla, que apenas pode ser entendido pela simultaneidade ou concomitância que lhe é característica: o Estado desaparece porque perde sentido em uma verdadeira democracia, na qual a emancipação humana e o comunismo finalmente serão realizados; e a verdadeira democracia, por sua vez, realiza-se com a conquista da emancipação humana e do comunismo, porque o Estado desaparece, e uma nova forma de organização política deverá surgir em seu lugar.

O Estado, portanto, representa apenas um dos conteúdos particulares da democracia, um de seus momentos, uma "forma particular de existência do povo" (Idem, ibidem), dentre outras formas possíveis. O sentido verdadeiro da democracia, entretanto, apenas revela-se quando ela se liberta do Estado e de toda forma de mediação política: "quanto mais a democracia se aproxima de sua verdade, mais o Estado decresce, conhece um processo de desaparecimento, isto é, deixa de exercer uma eficácia, uma dominação, enquanto parte que pretende valer pelo todo" (Abensour, 1998 [1997], p. 122). Se a existência da democracia no sentido verdadeiro é incompatível com o
Estado, resta buscar na comunidade uma nova forma de organização política na qual ela possa se desenvolver.

\section{A democracia como constituição genérica}

Marx antecipa, ainda na primeira metade do século XIX, algumas das conseqüências resultantes da contradição entre o Estado e a sociedade civil que viriam a se tornar ainda mais exacerbadas no século seguinte, particularmente em função do enrijecimento do modo de produção capitalista, o qual encontraria na separação entre as esferas socioeconômica e política um terreno bastante propício ao seu desenvolvimento.

A atomização em que mergulha a sociedade civil por seus atos políticos é uma conseqüência necessária do fato de a comunidade (Gemeinwesen), a essência comunista (das kommunistiche Wesen) na qual o indivíduo singular existe, a sociedade civil, ser separada do Estado. Ou em outras palavras: o Estado político é uma abstração da sociedade civil (Marx, 1992a [1843], p. 145).

A sociedade civil moderna, que segue ao Estado moderno, funda-se no individualismo e é incapaz de fazer do homem um ser social. Impondo aos indivíduos relações competitivas e conflitivas, a sociedade civil os torna seres isolados. Seus "atos políticos" - como é o caso do sufrágio e da representação - apenas aprofundam esse individualismo, restando aos homens viver em uma situação de atomismo que os separa até mesmo de si próprios. Não há outra conseqüência senão o encontro entre o estranhamento (Entfremdung) e a alienação (Entäusserung). É aqui que a verdadeira democracia se revela como enigma resolvido e apresenta-se como aquilo que pode interromper essa seqüência: a verdadeira democracia pressupõe a comunidade, que, por sua vez, transforma os indivíduos isolados em seres sociais justamente por meio do caráter político que assumem quaisquer de suas atividades, mesmo enquanto atividades individuais. Como na Grécia antiga, a separação entre o mundo privado e o mundo público se desfaz em nome da democracia verdadeira. Este desfazimen- 
to, contudo, não teria mais o custo da liberdade. Essa, afinal, a verdadeira unidade entre o político e o social a ser propiciada pela democracia.

Ao afirmar que a verdadeira democracia é o enigma resolvido de toda constituição, Marx quer dizer que a democracia se identifica com a realidade material - ou com a "vida do povo" -, não obstante a forma política que a contenha. Em outras palavras, o que define como verdadeira a democracia é a experiência humana que se encontra em sua base, e não as instituições de uma determinada forma de governo ou regime político que porventura a reclamem. Por isso a democracia apresenta-se como a "verdade de todas as constituições", uma "constituição genérica" que, no entanto, não tem qualquer forma política como a sua própria verdade.

Nos modelos originais de monarquia, democracia e aristocracia não havia inicialmente constituição política como distinta do Estado real, material, e dos demais aspectos da vida do povo. O Estado político ainda não aparecia como a forma do Estado material (Idem, p. 90).

A institucionalização da realidade material, seu aprisionamento em formas, é uma invenção do pensamento político moderno - invenção esta da qual Marx quer nos libertar. O pensamento político clássico, afinal, havia nos legado apenas uma preocupação com os regimes de governo, sem criar formas rígidas, como a própria idéia de constituição, que os separassem de seu conteúdo material, real, expresso na própria existência e experiência humanas. Observe-se que no trecho transcrito acima Marx apenas colocou lado a lado a democracia, a monarquia e a aristocracia com o fito de demonstrar como antes do pensamento político moderno converter a realidade em abstração não havia separação entre substância e forma. Com a modernidade, os regimes políticos passaram, na prática, a se organizar com base em tal separação. A abstração torna-se uma realidade, mas esta não se identifica mais com a vida do povo. O Estado moderno, afinal, instaura a alienação. E este passa a ser o problema não apenas da monarquia ou da aristocracia, mas também da república. Com efeito, em todas essas formas de governo apenas pode-se ter uma "democracia política" - o que equivale a dizer uma democracia liberal, burguesa; uma democracia como abstração: uma "democracia moderna". Por isso Marx fala em um "Estado político" como a forma do "Estado material" ou em uma "constituição política" distinta do "Estado real". A verdadeira democracia seria o "Estado material" ou "real" em oposição ao "Estado político" ou "constituição política" que é como Marx alternativamente se refere ao Estado moderno.

A democracia é a verdade da monarquia, mas a monarquia não é a verdade da democracia. A monarquia é necessariamente democracia como uma inconseqüência e excrescência, o aspecto monárquico não é uma inconseqüência da democracia. A democracia pode, e a monarquia não pode, ser concebida em seus próprios termos. Na democracia, nenhum aspecto recebe qualquer outro significado senão aquele apropriado para ele. Cada um é, na verdade, um aspecto do demos todo. Mas na monarquia uma parte determina o caráter do todo. A constituição inteira precisa conformar-se em função de um ponto fixo. A democracia é a constituição genérica. A monarquia é uma espécie, e de fato uma espécie ruim. A democracia é conteúdo e forma. A monarquia pode ser apenas forma, mas ela falsifica o conteúdo (Idem, p. 87).

Por que, afinal, a democracia pode ser concebida em seus próprios termos e a monarquia não, podendo aquela ser uma verdade desta, mas jamais o contrário? A comparação entre monarquia e democracia serve a Marx para mostrar a diferença existente entre forma e conteúdo. ${ }^{4} \mathrm{~A}$ monarquia é uma forma, uma forma política, como também é uma forma a república, a qual ele cita como exemplo em diversas passagens similares a esta. Já a democracia é um conteúdo sem forma determinada, um conteúdo que não pode ser traduzido por uma forma outra senão a deste próprio conteúdo. Por isso a democracia pode ser concebida em seus próprios termos, pois que é concomitantemente forma e conteúdo. Uma monarquia pode ser democrática, assim como uma república pode ser democrática, mas uma democracia não é, ela mesma, uma democracia monárquica ou uma democracia republicana: a democracia é a verdade da monarquia (como poderia ser a verdade da república), mas a monarquia não é a verdade da democracia. A 
monarquia ou a república são apenas formas que falsificam o conteúdo, isto é, falsificam a democracia. Colocado este ponto em outra perspectiva, temos que a democracia é o sujeito, enquanto a monarquia ou a república são predicados que podem ou não acompanhar tal sujeito. O sujeito existe por si só, mas o predicado necessita do sujeito para completá-lo, sem o que ele não tem sentido, não atinge a sua verdade.

Hegel parte do Estado e concebe o homem como o Estado subjetivizado; a democracia procede do homem e concebe o Estado como um homem objetificado (Idem, ibidem).

Quando Marx afirma que, ao contrário do que pensava Hegel, a democracia deve partir do homem e não do Estado, ele quer dizer que este assim como as formas monárquica ou republicana que porventura assuma - pode, quando mais, ser apenas um reflexo do homem, uma de várias formas particulares da vida do povo, uma das várias determinações que o conteúdo da democracia pode assumir. Quando a democracia parte do homem, ela pode ou não chegar ao Estado, fazer dele seu objeto, seu predicado, um "homem objetificado". Este não é um caminho necessário. Fazer do homem, e não do Estado, o sujeito, implica que a democracia pode existir sem o Estado, que ela não é uma característica ou uma determinação dele. Justamente o contrário: como conteúdo, a democracia não pode ser aprisionada em formas, ela pode apenas percorrê-las, o que faz com que a dinamicidade de seu movimento natural se cristalize em momentos. Na condição de movimento, a democracia desenvolve-se como um processo; na condição de momento, a democracia manifesta-se molecularmente. Cada aspecto da democracia, cada uma de suas partes, é apenas um aspecto do demos, do demos todo. Não há distinção entre o todo e suas partes: ambos remetem ao povo, à vida do povo, não se distinguindo entre si. A verdadeira democracia consiste em um todo unitário, e é isso que permite que ela seja, concomitantemente, conteúdo e forma: seu conteúdo dá forma a si mesmo, permanentemente. É por isso que a democracia parte do homem: ele é o sujeito da democracia, o que equivale a dizer que ele é o seu conteúdo. A democracia identifica-se com a experiência do homem, com sua atividade, com sua prática, com sua vida. É assim que a democracia se faz conteúdo e o pode refletir em distintas formas que, no entanto, com ele não se identificam. É nesse sentido que a democracia é a "constituição genérica".

A democracia é a essência de todas as constituições políticas, o homem socializado (des sozialisierten Menschen) como uma constituição política particular. A democracia está para as outras formas de constituição como o gênero está para as suas várias espécies, à diferença apenas que aqui o gênero passa a existir e se manifesta como uma espécie particular em relação às outras espécies, cuja existência não corresponde à essência genérica (Idem, p. 88).

O que significa dizer que "a democracia é a essência de todas as constituições políticas"? O que Marx entende por "constituição política"? Segundo Avineri, onde Marx escreve "constituição política", devemos ler "Estado". Essa interpretação parece-me limitada, na medida em que, neste contexto de definição do estatuto da verdadeira democracia, "constituição política" implica, de fato, algo mais genérico, tal como 'forma política' ou 'organização política'. De acordo com esse último sentido, o Estado poderia ser uma forma de organização política, assim como a comunidade poderia ser outra dessas formas. Desse modo, a organização política consiste em uma instância genérica, da qual emanam formas particulares por meio das quais a política se processa. Tais formas podem ser tão diversas quanto o são a comunidade e o Estado, lembrando que este último ainda é suscetível de outras instâncias de particularização interna (formas de Estado e formas de governo). Vale lembrar que o uso do termo "constituição" neste sentido genérico de forma de organização política é também usado por Spinoza, e encontra ainda um significado semelhante àquele visado por Aristóteles ao se referir à politeia como uma forma de organização política da polis. Logo, afirmar que a democracia é "a essência de todas as constituições políticas" implica confirmar que a democracia é uma substância sem forma, que pode potencialmente se materializar em diferentes contextos de organização da política. No entanto, se todas as formas políticas podem ter a democracia como sua verdade, a recíproca não se aplica: a demo- 
cracia apenas encontra sua verdade na comunidade que supera o Estado moderno.

Isso remete a outra das questões suscitadas na passagem transcrita acima, qual seja, a de que "a democracia está para as outras formas de constituição política como o gênero está para a espécie". A democracia é um gênero do qual o Estado em sua forma monárquica ou o Estado em sua forma republicana constituem apenas espécies. Ela é uma essência da qual emanam todas essas "constituições políticas". Mais uma vez, a democracia é uma substância que pode ou não preencher as formas políticas. Todas a almejam como sua essência, como sua verdade. Nesse sentido são apenas "espécies", "momentos", "expressões particulares", "determinações" da democracia. De onde se explica ainda que "a democracia é [...] o homem socializado como uma constituição política particular". A democracia remete ao homem, e ao homem socializado, isto é, o homem como ser social, como parte constitutiva e constituinte da sociedade. Esse "homem socializado", ou a "vida do povo", apresenta-se, por sua vez, como uma "constituição política particular", ou seja, a manifestação do gênero que passa a existir e a se manifestar "como uma espécie particular em relação às outras espécies, cuja existência não corresponde à essência genérica".

A unidade da sociedade civil com o Estado conduz à unidade do indivíduo e do cidadão, do particular e do universal. Não há mais partes que se sobreponham umas as outras, determinando-se exteriormente. O todo formado por esta unidade determina-se a si mesmo. Isso propicia que o enigma, afinal, se resolva:

A democracia é o enigma resolvido de toda constituição. Nela encontramos a constituição fundada em sua verdadeira base: seres humanos reais e o povo real; não meramente, implicitamente e em essência, mas em existência e em realidade. A constituição é assim postulada como criação própria do povo. A constituição é, em aparência, o que é em realidade: a criação livre do homem (Idem, p. 87).

Os homens devem ter controle das condições de sua própria existência. A autodeterminação apresenta-se como determinação da universalidade em cada evento que singulariza o sujeito.
O político deve organizar-se não com base em um artefato jurídico, mas a partir dos próprios "seres humanos reais", em sua atividade de determinar-se a si mesmos, de consolidar a sua existência como sujeitos. Não basta ao povo existir; para ser real ele tem que intervir diretamente na realidade, constituindo-a, fazendo dela parte de si mesmo, na medida em que ela também se organiza de acordo com a ação dos homens. A forma política que resulta dessa organização não pode ser senão uma criação própria do povo, um resultado de sua capacidade de determinar-se a si próprio. Enquanto "criação livre do homem", a democracia prescinde de formas jurídicas. Ela deixa, aliás, de ser uma forma, para ser simplesmente o conteúdo resultante das capacidades criativas e criadoras dos sujeitos. A democracia combina abertura e reflexividade; ela se exerce verdadeiramente como uma atividade, e uma atividade do povo. ${ }^{5}$

Em vez de definir-se como um vínculo jurídico-político que une os homens ao Estado, a cidadania passa a se definir ativa e efetivamente como a prática democrática dos homens que é constitutiva de sua própria forma de organização política. Cidadania "ativa" deixa de ser algo que é conceituado em contraposição a um sentido "passivo", para remeter diretamente ao sentido de atividade. Os cidadãos são ativos não porque deixam de ser passivos, mas porque é a sua própria atividade que passa a definir a cidadania. Nesse sentido, toda atividade humana, todas as ações do homem são constitutivas da cidadania. Em outras palavras, com a verdadeira democracia, toda atividade humana é preenchida de sentido político.

Quando não há mais separação entre uma esfera política e outra socioeconômica, vale dizer, quando a verdadeira democracia possibilita que a comunidade surja no espaço onde antes havia a separação entre sociedade civil e Estado, todas as ações dos homens passam a ser ações políticas. Marx reconhece um caráter político à prática, identificando toda atividade individual como atividade política. Não há separação entre o que seja uma tarefa particular e uma tarefa pública: quando o universal e o particular encontram-se, todas as atividades individuais passam a ter um sentido público, dizem respeito à gestão coletiva da comunidade. Conforme esclarece sobre este ponto Henry, 
[...] o político não se refere mais ao Estado, nem a uma atividade específica do Estado. A significação política da atividade de um indivíduo [...] deve qualificar sua atividade individual como tal, sua atividade cotidiana, profissional e pessoal (Henry, 1976, p. 136).

É nesse sentido, afinal, que a verdadeira democracia se apresenta como um enigma resolvido, e não meramente como um enigma. Os homens tornam-se sujeitos reais na medida em que ganham consciência de si, e esta consciência os torna seres socialmente políticos. Não há distinção entre o individual, o social e o político, uma vez que toda atividade individual é também uma atividade social com efeitos políticos. A atividade pessoal e profissional dos indivíduos mescla-se com a administração das coisas públicas, de modo que a prática cotidiana da democracia é constitutiva, ao mesmo tempo, da comunidade e dos homens que nela vivem.

Assim, já de posse da resolução de seu enigma antes mesmo de formulá-lo na Crítica da filosofia do direito de Hegel, Marx escreveu em carta enviada a Ruge em maio de 1843:

Apenas o sentimento próprio dos homens, sua liberdade, pode fazer a sociedade novamente um dia tornar-se uma comunidade na qual os homens possam realizar seus objetivos mais elevados, uma polis democrática (Marx, 1992b [1843], p. 201).

\section{Considerações finais}

Quando Marx afirma que a verdadeira democracia é o enigma resolvido de toda constituição, ele está a dizer, em outras palavras, que a democracia é a verdade de todas as formas de organização política. Mas, em contrapartida, se o Estado moderno consiste em apenas "um momento" ou em "uma forma de existência particular" da democracia, há apenas um tipo de organização política que se identifica com o conteúdo da verdadeira democracia, qual seja, a comunidade. $\mathrm{Na}$ comunidade, a democracia atinge a sua verdade: revela-se como a forma da "sociedade comunista" ou a "sociedade do futuro", isto é, a "sociedade sem classes" ou a "sociedade sem Estado", que viria a servir de lugar para a realização do comunismo após uma revolução que fizesse com que a idéia moderna de Estado desvanecesse, e não simplesmente postulasse que o poder fosse tomado por novos sujeitos. Afinal, o enigma para o qual aponta a verdadeira democracia não diz respeito à titularidade do poder ou à forma de seu exercício. O enigma da democracia aponta para a contradição que se encontra na base da modernidade política, isto é, a separação do Estado em relação à sociedade civil e a conseqüente alienação política desta em face daquele.

É por isso que, conforme argumentei ao longo deste artigo, pensar a democracia com Marx implica pensar uma nova forma de organização política que resolva a contradição entre Estado e sociedade civil. Esta contradição, que responde por tantos dualismos que caracterizam a modernidade política desde a Revolução Francesa, não será definitivamente superada por mediações - como a representação política -, que apenas propiciam à sociedade civil uma "existência política ilusória”, conforme já percebia Marx. Apenas uma nova forma política que ofereça espaço para que aquela contradição a um só tempo se realize e se resolva poderá tornar a democracia verdadeira. É assim que Marx fornece uma resposta atual para um problema moderno que ainda nos é contemporâneo: a resolução do enigma deve ser buscada nas formas comunitárias que realizam a democracia sem mediações, por meio da multiplicidade da experiência humana e da prática constitutivamente política dos homens.

\section{Notas}

1 Quando anuncia "uma democracia bastante diferente que representa o meio-termo entre as democracias grega, romana, americana e francesa", Engels denuncia algumas das fontes de Marx ao elaborar o conceito de verdadeira democracia. As lições sobre o modelo romano, Marx tomou de Robespierre e de seu extenso estudo sobre Revolução Francesa, em particular do jacobinismo. Marx nutriu-se do culto jacobino à antiguidade clássica, muito embora achasse que um de seus erros estratégicos foi o de tentar transpor forçosamente princípios da antiguidade para os tempos modernos. Quanto à democracia grega, Marx certamente se valeu de estudos sobre a Atenas de Péricles. Sabe-se que a democracia ateniense e a antiguidade clássica em geral faziam parte 
do currículo universitário de Marx, afinal na Alemanha das primeiras décadas do século XIX a admiração por aquela época histórica acompanhada de um estudo sistemático da mesma era algo recorrente. No que tange à democracia americana, há indícios interessantes nos cadernos de estudo de Marx do mesmo ano de 1843 em que ele propôs o conceito de verdadeira democracia. Um desses cadernos traz inúmeras citações de Thomas Hamilton, mais especificamente de sua obra Men and manners in America, publicada pela primeira vez em 1833. Marx, que leu Hamilton traduzido em alemão, copiou cerca de cinqüenta passagens de seu livro, que versavam majoritariamente sobre os seguintes temas: federalismo, sufrágio universal, situação jurídica dos cidadãos (questões de cidadania), constituições dos estados americanos, conflitos de interesse entre o norte e o sul, entre outros. Se Marx busca na democracia americana sinais de sua potencialidade revolucionária, é certo que nas páginas de Hamilton - particularmente em sua observação da economia americana - encontrou o suor das lutas de classe. Sabe-se ainda que neste período Marx também leu Tocqueville, muito embora seus cadernos de estudo não tragam evidências explícitas disso. Esta influência se faz sentir não apenas em conjugação com aquela exercida por Hamilton, no que tange ao provimento de um retrato empírico da democracia norte-americana, como também mais diretamente no conteúdo de alguns artigos publicados na Gazeta Renana no período que precedeu a redação da Crítica da filosofia do direito de Hegel. A influência da democracia francesa na sua concepção de verdadeira democracia, particularmente dos teóricos franceses da democracia, é decisiva. Uma das principais idéias que Marx parece querer reter de tal influência diz respeito à impossibilidade da realização da democracia dentro dos limites do Estado. A verdadeira democracia engendra uma tensão entre democracia e Estado, como se estes dois conceitos fossem incompatíveis; como se, onde existisse o Estado, a democracia não fosse possível, pelo menos não em sua forma verdadeira. Entretanto, é a influência do socialismo francês que parece ter sido determinante. Além de Fouret e Saint-Simon, sabe-se que Marx leu com atenção Victor Considerant, considerado uma de suas influências mais importantes ao conceber o conceito de verdadeira democracia. Um dos principais discípulos de Fourier e um dos mais importantes difusores diretos e indiretos de sua obra, Considerant publicou no mesmo ano em que Marx redigiu a Critica da filosofia do direito de Hegel o seu Manifeste de la démocratie au XIX siècle, na forma de uma introdução ao seu jornal La démocratie pacifique, que veio a substituir o jornal fourierista La Phalange. Na última parte deste belo manifesto, após distinguir entre as tendências imobilista, conservadora, retrógrada, revolucionária e progressista da democracia, Considerant elabora uma distinção entre o que seria uma "democracia verdadeira" e uma "democracia falsa". A primeira consistiria no "pleno reconhecimento dos direitos e interesses de todos, e sua efetiva organização progressiva e inteligente". Além disso, ela implicaria na "organização regulada da paz e do trabalho, no desenvolvimento de prosperidade nacional e a realização progressiva da ordem, da justiça e da liberdade", e resultaria em uma "organização hierárquica das famílias e das classes em uma commune, as communes nas províncias na nação. E a associação das nações na humanidade". Já a "falsa democracia" se identificaria com o "espírito revolucionário" (!), o "espírito da inveja, do ódio, da guerra", pregaria a "liberdade anárquica, a igualdade violenta e cobiçosa, o patriotismo exclusivo e dominador", além da "independência feroz, caótica, armada e hostil". Desse modo, a "verdadeira democracia" "une, organiza, relaciona, classifica, associa, libera e centuplica o bem-estar e o desenvolvimento físico, moral e intelectual de todas as pessoas, de todas as classes". A "falsa democracia", por sua vez, "divide, subverte, destrói, empobrece e cobre a terra com ruínas. Ela incita as classes umas contra as outras e os povos contra os seus governos". É assim que Considerant irá concluir que o "espírito moderno" se bifurca em duas expressões opostas, a "democracia pacífica", que ele advoga como verdadeira, e a "democracia violenta e revolucionária", a falsa democracia que a ela se oporia (Considerant, 2006 [1843], pp. 91-92).

2 Este ponto encontra-se desenvolvido em Pogrebinschi (2007, caps. 1 e 2).

3 Quem seriam estes franceses de quem Marx toma a lição sobre o desaparecimento do Estado? Não há um consenso a esse respeito entre os diversos comentadores. As hipóteses variam entre Victor Considerant (Abensour, 1998 [1997], p. 139), Proudhon e Fourier (Draper, 1970, p. 283), ou ainda outros revolucionários franceses como Saint-Simon e Robespierre. Com efeito, os cadernos de estudo de Marx referentes ao período entre 1842 e 1843 indicam um estudo atento da Revolução Francesa e de seus líderes, bem como do socialismo que a partir de então se fez emergente naquele país, para onde viria a se mudar no ano seguinte. Não é de se descartar ainda que, como bom jovem hegeliano que era até mesmo em sua refuta- 
ção de Hegel, Marx tenha se nutrido também das idéias de um curioso documento que remonta às origens do Idealismo alemão: "O mais antigo programa de sistema do idealismo alemão", manuscrito anônimo de origem supostamente coletiva, mas por muitos atribuídos à pena solitária de Schelling. Neste pequeno e surpreendente documento de cunho inegavelmente kantiano, encontra-se um ataque peculiar à idéia de Estado (e, como decorrência, a desconstrução das idéias de governo, constituição e lei) que se faz acompanhar pela defesa irrestrita de sua superação. O Estado, para este idealismo que parecia ainda não ter-se separado do romantismo, não podia ser tomado propriamente como uma "idéia", reduzindo-se a uma espécie de máquina que se relaciona com os homens como se eles fossem engrenagens mecânicas. Para que a "idéia" dentre todas superior, qual seja, a de um ser absolutamente livre, pudesse se fazer plena, decorria a necessidade do desaparecimento do Estado, após o que se estabeleceria um "mundo moral" que pudesse realizar a razão que ele apenas simulava. A verdadeira democracia, no entanto, em nada se assemelha a este universo moral almejado nos primórdios do Idealismo alemão senão em sua estratégia de constituir-se a si mesma em contraposição ao Estado e com ele mostrar-se irreconciliável. "Das älteste Systemprogramm des deutschen Idealismus", escrito entre 1796 e 1797, é usualmente atribuído conjuntamente a Hölderlin, Hegel e Schelling, embora seu conteúdo seja extremamente similar à obra posterior deste último.

4 Vale recordar, a título de curiosidade, que no âmbito do jusnaturalismo moderno faz-se freqüentemente uma distinção entre Civitas e Respublica, as quais são relacionadas como materia e forma, ou subjectum e finis, ou corpo e alma. A Civitas consiste no grupo ou comunidade que é a base do Estado, enquanto a Respublica é a constituição daquele grupo; desse modo, a Civitas é definida como um corpo de pessoas, e a Respublica, como uma ordem de relações. Ainda, a idéia de societàs liga-se à primeira, e a idéia de summa potestas, à segunda (cf. Gierke, 1958, p. 235).

5 A influência de Spinoza na concepção marxiana de democracia pode ser percebida aqui. Spinoza é uma das peças-chave para se entender a démarche intelectual que leva Marx à democracia, e desta ao comunismo. Foi na escola de Spinoza que Marx teria, afinal, aprendido a conciliar necessidade e liberdade, e uma vez de posse desse conhecimento lhe foi possível desconstruir a mistificação hegeliana, em particular sua metafísica do Estado. A relação inseparável entre a democracia e o homem e entre este e a liberdade, Marx certamente traz de Spinoza. O filósofo holandês, afinal, responderia aquilo que ele teria em vão demandado de Hegel ou Rousseau: a possibilidade de o indivíduo reconciliar existência social e direito natural sem fazer recurso a uma ficção jurídica (um contrato social no qual se transfiram direitos e por meio do qual se constituam a soberania e a representação). A associação, conceito que Marx desenvolve inspirado em Spinoza, possibilita que a democracia seja realizada em uma forma de organização política na qual a permanência do chamado "estado de natureza" impede a separação entre a sociedade civil e o Estado. Marx encontra em Spinoza a idéia de uma democracia total, e dela se beneficiará posteriormente sua noção de comunismo.

\section{BIBLIOGRAFIA}

ABENSOUR, Miguel. (1998) [1997], A democracia contra o Estado: Marx e o momento maquiaveliano. Belo Horizonte, Editora da UFMG.

AVINERI, Shlomo. (1968), The social and political thought of Karl Marx. Cambridge, Cambridge University Press.

CONSIDERANT, Victor. (1843 [2003]), Principles of socialism: Manifesto of 19th Century democracy. Washington, Maisonneuve Press.

DRAPER, Hal. (1977), Karl Marx's theory of revolution. Vol. 1: State and bureaucracy. Nova York, Monthly Review Press.

ENGELS, Frederick. (1845), "The festival of nations in London", in Marx and Engels collected works, vol. 6. Nova York, International Publishers.

GIERKE, Otto Von. (1958), Natural law and the theory of society. Cambridge, Cambridge University Press.

HENRY, Michel. (1976), Marx I: une philosophie de la réalité. Paris, Gallimard.

MARX, Karl, (1976 [1867], Capital. Londres, Penguin Books, vol. 1.

1992a [1843]. Critique of Hegel's doctrine of the State, in Karl Marx: Early wri- 
tings. Traduzido por Rodney Livingstone. Londres, Penguin Books.

(1992b [1843]), Letters from the Franco-German yearbooks, in Karl Marx: Early writings. Traduzido por Rodney Livingstone. Londres, Penguin Books.

POGREBINSCHI, Thamy. (2007), O enigma do político: Marx contra a politica moderna. Tese de doutorado em Ciência Política, Rio de Janeiro, Iuperj. 


\section{O ENIGMA DA DEMOCRACIA EM MARX}

Thamy Pogrebinschi

Palavras-chave: Karl Marx; Democracia; Estado; Comunidade.

O objetivo deste artigo consiste em examinar o conceito marxiano de verdadeira democracia, tal como desenvolvido, sobretudo, na Crítica da filosofia do direito de Hegel, de modo a indicar a maneira pela qual ele se apresenta como o "enigma resolvido" das formas modernas de organização política. Nesse sentido, argumento que esse enigma aponta para a contradição entre o Estado e a sociedade civil, que, para Marx, constitui a principal característica da modernidade política. Em conseqüência, argumento também que como solução do enigma que revela, a "verdadeira democracia" implica na superação daquela contradição, a qual apenas pode se dar mediante a criação de um novo lugar para a política: a comunidade real fundada em uma livre associação de homens igualmente livres.
DEMOCRACY ENIGMA IN MARX

Thamy Pogrebinschi

Keywords: Karl Marx; Democracy; State; Community.

This article aims at analyzing the concept of Marx on true democracy as developed especially in the Critique of Hegel's Philosophy of Right, in order to indicate how he poses himself as the "resolved enigma" for modern ways of political organization. In doing so, the article argues that such enigma points towards the contradiction between state and civil society, which for Marx constitutes the main characteristic of political modernity. It consequently also argues that a solution revealed to the enigma of the "true democracy" implies in overcoming contradiction, what can only happen through the instauration of a new place for politics: the real community founded on free association of equally free men.
L'ÉNIGME DE LA DEMOCRATIE D'APRÈS MARX

Thamy Pogrebinschi

Mots-clés : Karl Marx; Démocratie; État; Communauté.

L'objectif de cet article est d'examiner le concept de la véritable démocratie selon Marx, tel qu'il a surtout été développé dans la Critique de la philosophie du droit de Hegel, de façon à indiquer la façon par laquelle il se présente comme l'"énigme résolue" des formes modernes de l'organisation politique. Ainsi, je défends que cette énigme indique la contradiction existante entre l'État et la société civile, qui, pour Marx, a été la principale caractéristique de la modernité politique. En conséquence, je défends également que la "véritable démocratie", en tant que solution de l'énigme qu'elle révèle, implique le surpassement de cette contradiction, qui ne peut exister que par la création d'un nouvel emplacement pour la politique: la communauté réelle fondée sur une libre association d'hommes également libres. 